\title{
WAPEN- EN UNIFORMHISTORISCH COMMENTAAR OP DE TABAKSDOOS UIT SRI LANKA
}

DE VOORSTELLING op het deksel van de tabaksdoos is heel interessant, want hij toont rechts twee kennelijk Europese soldaten (afb. 1). Zij dragen beide dezelfde monteering (uniform), bestaande uit een korte dichtgeknoopte tuniek, een kniebroek en op het hoofd een driekante steek. De soldaat rechts houdt een snaphaan (vuursteengeweer) vast met 'opgeplante' bajonet, waarvan de kling een eigenaardige vorm heeft. Overigens is deze bajonet wat de wapenhistorici een sokkelbajonet noemen, dat wil zeggen een waarvan de greep uit een ijzeren huls bestaat die over de monding van de geweerloop wordt geschoven. Op de steken is geen embleem zichtbaar, de tunieken hebben elk in het midden één verticale rij nauw aaneengesloten knoopjes. Het internationaal gangbare soldatenuniform in de achttiende eeuw bestond uit een kniebroek als ondergoed, dat wil zeggen elk onder de gordel gedragen kledingstuk, een mouwvest of kamizool met één rij knoopjes, en een lakense rok (jas) met lange panden waarvan de voorzijden weggeslagen en zodanig vastgeknoopt waren dat beide panden elk in een puntvorm eindigden. De rok had voorop een lange rij knopen (soms twee rijen) alsmede rechthoekige rabatten (revers) en onderaan de mouwen brede opslagen afgezet met knopen.

DE ERVARINGEN OPGEDAAN bij de veldtochten tijdens de oorlog tegen Kandy (Kandia), 1762-1764, noopten de VOC-autoriteiten om de soldaten uit te rusten met aan de gevechten in de tropische jungle aangepaste bewapening, uitrustingsstukken en uniformen. Allereerst moesten de gangbare uniformen het ontgelden, want de lange rokken werden '...in de bosschen en doornheggen verscheurt' en hun panden raakten '...aen flarden'. Eenmaal nat geworden droogde de lakense stof slechts zeer langzaam. De gouverneur van Ceylon van 1761-1765, L.J. baron van Eck, liet nu velduniformen, in feite dus gevechtsuniformen invoeren, bestaande uit '...borstrokken met overslaende kleppen en lange broeken,' beide van linnen ('Atoers tverndoek'). De driekante steek verviel en werd vervangen door een zeildoekse hoed met opstaande randen die ook neergeslagen konden worden, en met het regimentsembleem op de bol. Verder kregen zij een schroefmes mee, een soort combinatie van een wapen en een stuk gereedschap, want de pareerstang was aan zijn ene uiteinde gevormd als hamer, aan zijn andere als schroevendraaier. Bovendien werd aan de soldaten een grote linnen tas uitgereikt die zij aan een draagband over de linkerschouder droegen en die op de rechterheup rustte. De geweerbajonet werd aan deze tas bevestigd. In de tas zaten 48 geheel klaargemaakte papierpatronen (waarin kogel en kruitlading tezamen verpakt waren), het genoemde schroefmes, twee vuurstenen, een krasser (om de ziel van de geweerloop te reinigen en om vastzittende kogels eruit te peuteren), een olieflesje, wat oud linnen (om te verscheuren tot proppen die op de lading in de loop werden gezet opdat de kogel er niet voortijdig uit rolde) en 


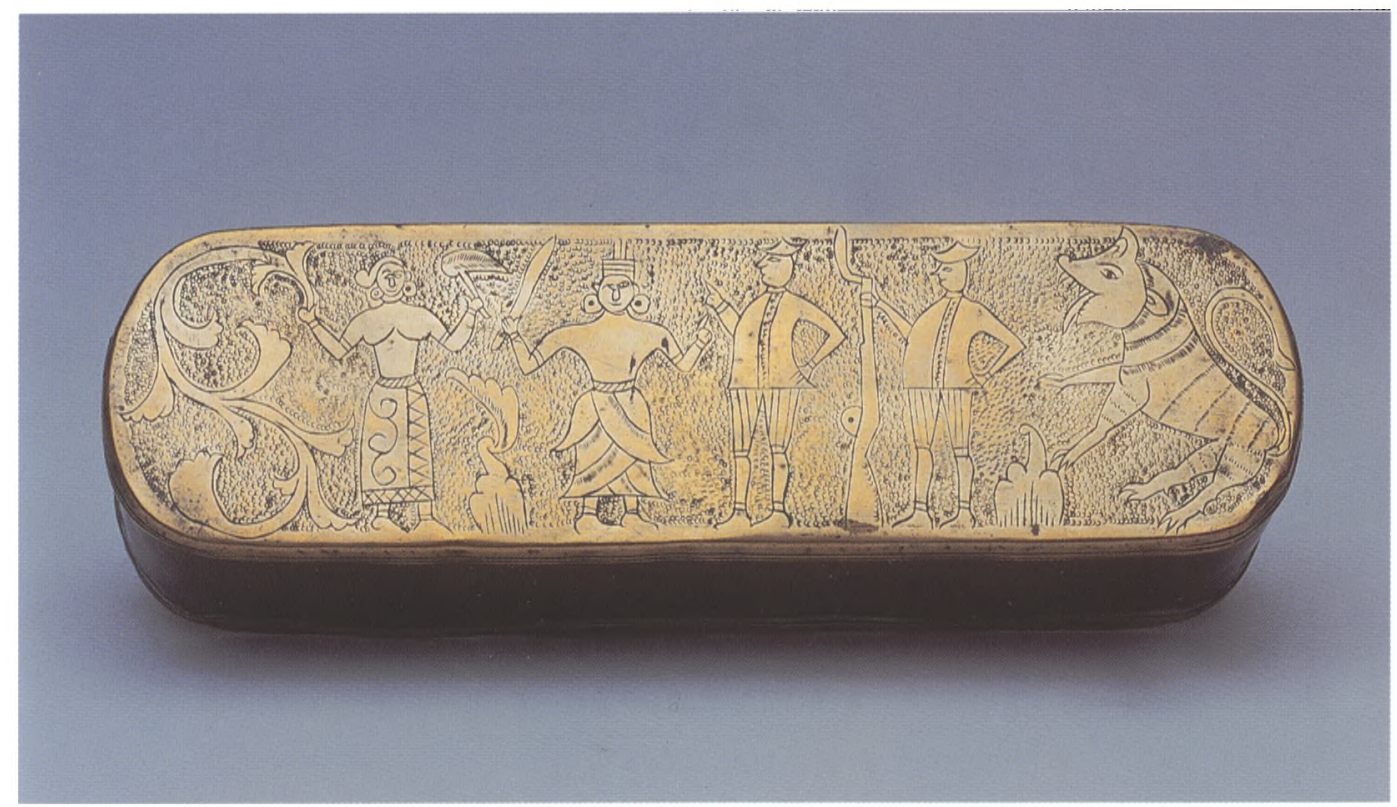

Afbeelding 1 Tabaksdoos, koper. Particuliere verzameling. twee zundgatprikkers (door kruitslijm koekte het zundgat, waar doorheen de lading in de loop werd ontstoken, snel dicht). Ook werd geëxperimenteerd met een opplantbare bajonet waarvan de kling kort en breed was als een soort hakmes. Deze bajonet moest dan tevens de gangbare kostuumdegen vervangen die in het junglegevecht vrijwel onbruikbaar was.

IN HET LICHT van deze uitvoeringen bezien, kan de voorstelling op de tabaksdoos leiden tot de voorzichtige conclusie dat hij VOC-soldaten van na 1764 toont, immers de overhemdachtige borstrok - in feite een tot tuniek veredeld kamizool - is duidelijk zichtbaar en ook heeft de bajonet een brede kling van hakmes-vorm. Dat de soldaten desalniettemin een soort geformaliseerde versie van het in 1764 ingevoerde veldtenue lijken te dragen, komt door het feit dat geen degens of sabels gedragen worden, door de korte broeken en de driekante steken en het ontbreken van de eerder genoemde uitrustingsstukken, wat natuurlijk bij min of meer formele gelegenheden, zoals de voorstelling lijkt te suggereren, een strakker militair uiterlijk gaf.

In miln bildrage 'Oorlogvoering op Ceylon in de V.O.C.-tijd' in: R. Kromhout (Red.), Het Machtige Eyland: Ceylon en de V.O.C. ('s-Gravenhage: SDU, 1988), p.64-70, ga ik nader in op de boven genoemde bijzonderheden. Ik heb mij daarbij gestoeld op het voortreffelijk archiefonderzoek van R. Raven-Hart, neergelegd in zijn werken The War with the Sinhalese (Colombo 1961) en The Dutch Wars with Kandy 1764-1766 (C. 1964). 